\section{Max M. Kampelman Receives 1989 Pi Sigma Alpha Award}

Ambassador Max M. Kampelman, political scientist, lawyer and diplomat received the National Capital Area Political Science Association 1989 Pi Sigma Alpha Award at the spring conference of the Association March 4 at Mount Vernon College.

Howard Penniman, National Director of Pi Sigma Alpha, made these remarks in presenting the award:

The National Capital Area Political Science Association presents its Pi Sigma Alpha award each year to a political scientist who has made a major contribution to the relationship between political scientists and public service.

- It is very appropriate to give the 1989 award to Max M. Kampelman who has just returned to his private law practice after devoting much of the past decade to public service. During that period, he was appointed by President Jimmy Carter and reappointed by President Ronald Reagan to serve as Ambassador and Head of the U.S. Delegation to the Conference on Security and Cooperation in Europe which was held in Madrid from 1980 to 1983. He was later Ambassador and Head of the U.S. Delegation to the Negotiations on Nuclear and Space Arms, Geneva, 1985 to 1989. He was appointed by President Carter to the Board of Trustees of the Woodrow Wilson International Center for Scholars, served as its Chairman from 1979 to 1981, and remains a Trustee. He was a member of the Presidential Delegation to the inauguration of President Jose Napoleon Duarte in 1984 in El Salvador.

After listening to a partial list of Kampelman's activities, it should come as no surprise to learn that we are not the first to honor him for his work.

A list of his major awards covers more than a single-spaced page:

President Reagan presented him "The Presidential Award Medal," January 1989.

"The Secretary of State's Distinguished Service Award" was presented to him in July 1988.

The Jewish Institute of National Security Affairs gave him the "Henry M. Jackson Award" in November 1987.

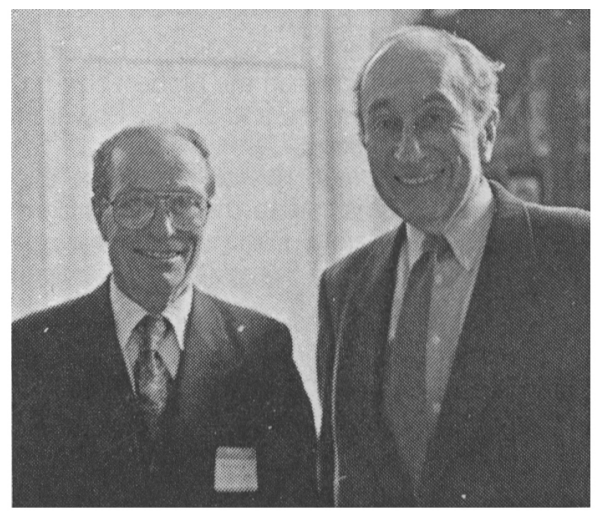

Ambassador Max M. Kampelman (r.) accepts Pi Sigma Alpha Award from Howard Penniman.

West Germany awarded him the "Knight Commander's Cross (Badge and Star) of the Order of Merit of the Federal Republic of Germany" in May 1984.

The Anti-Defamation League, presented him "Hubert $\mathrm{H}$. Humphrey First Amendment Freedoms Prize" in June 1982.

The American Political Science Association presented him its Hubert $\mathrm{H}$. Humphrey Award in 1987.

It takes more than two single-spaced pages simply to list institutions which Max helped to create or which he advised or served in some capacity. He was a member of the governing board of such schools as Georgetown University, Hebrew University, New York University, the University of Tel Aviv, the College of the Virgin Islands, and Mount Vernon College. And, he was President of the Nahinae Capital Area Political Science Association in 1955.

In all, there are roughly forty such organizations to which Kampelman has given time, guidance, funds, or, more likely, all three. We need to remember that Max does not ally himself to an institution to gain another title. More than almost anyone most of us will ever know, Max allies himself to an organization because he believes it is important and that he can make a contribution, and then he works.

Let me add one more note. One of his great admirers was the late Senator Henry $M$. Jackson of Washington State who spoke at length about Kampelman and his achievements at the Madrid Conference in 1983. After earlier high praise, Senator Jackson said: "He (Max) is the epitome of the Citizen-[. plomat -an example for others to 
try to follow." Jackson closed his remarks by saying, "I for one would-if I couldaward Max Kampelman the Nobel Prize for Coalition Management and Staying Power in Adversary Relations."*

It is a pleasure, Max, to represent this plaque and humanitarian check to you from the National Capital Political Science Association as its 1989 Pi Sigma Alpha Awardee.

*Congressional Record, March 15, 1983

\section{National Endowment for the Humanities Funds Increased for 1989}

John Hammer

Director

National Humanities Alliance

With the President's signature on the Interior and Related Agencies appropriation for fiscal year 1989 secured three days earlier, the National Endowment for the Humanities (NEH) began the new fiscal year on October I, 1988 with nearly 10\% more funds than in the just completed year. The $\$ 12,565,000$ increase this year is almost entirely apportioned to two operational areas of the NEH: the Office of Preservation (\$8 million increase) and the Division of State Programs (up $\$ 3.7$ million).

Contrary to folk wisdom about Presidential election years, the NEH budget process was vigorous and innovative. Following the routine development of the budget within the Administration (which is largely screened from outsiders and not reported here) major themes in 1988 included:

The annual budget request delivered on February 18, in which the Administration for the first time in seven years offered recommendations of level funding rather than reductions from current spending levels for $\mathrm{NEH}$ and its sister agencies, the National Endowment for the Arts (NEA) and the Institute of Museum Services (IMS). In recent years, the budget dynamic between the executive and legislature was in a sense based upon the Administration always urging cuts and the Congressprodded by Rep. Sidney Yates (D-IL)-declining to accept the reductions. The net result has been that the humanities funding was mostly flat with an easing downward due to inflation. With the FY- 89 proposals, that dynamic changed.

The disparity in appropriations for the arts and humanities endowments has been a budget reality since their establishment in 1965.

NEH staff have been privately annoyed by the growing gap in the two agencies' budgets which has increased steadily over the last decade (e.g., in FY.88, the gap was $\$ 29,296,000$ ). Perhaps in part because the struggle between reductions and hold-theline budgets abated this year, parity was openly discussed in the House hearings both in testimony from witnesses and in questions from Mr. Yates. For Congress in general and Mr. Yates in particular, simple comparisons of-or complaints aboutthe parity gap is not a credible issue. On the other hand, discussion of underfunding or non-funding of important work in the humanities (and an implicit or explicit relationship with parity) became a major theme during the hearings. The issue was raised at the March 17 outside witness hearing, notably by Nancy Stevenson and James Veninga (testifying for the Federation of State Humanities Councils) and Vartan Gregorian. During the agency hearing held April 21-in the context of an extended exchange with NEH Chairman Lynne Cheney on the adequacy of NEH appropriations-Mr. Yates remarked that he would like to see "a return to a level playing field" in the funding of arts and humanities. Both the Federation and the Alliance included statements on parity in testimony before the Senate Appropriations Subcommittee during a May 9 hearing.

The adequacy of funds at NEH has long been an issue between the Congress and the Administration. This year there was a noticeable movement toward addressing the issue more realistically. There were probably several factors in the enhanced attention, including the interplay of the issue with parity and the accumulating 